\title{
CONFERENCE OF RED CROSS AND RED CRESCENT SOCIETIES IN JAKARTA
}

The second conference of National Red Cross and Red Crescent Societies of the Asean countries met in Jakarta from 15 to 18 July under the chairmanship of Dr. Satrio, President of the Indonesian Red Cross. At the opening ceremony the conference was honoured by an address by His Excellency General Suharto, President of the Republic of Indonesia.

After welcoming the participants, General Suharto stated: "I am indeed happy to observe that with the existing co-operation among the Red Cross and Red Crescent Societies within Asean our joint efforts will certainly bring about greater results than what we can accomplish if we work individually... Co-operation based on humanism for humanitarian purposes will grow closer, and hopefully this would serve as a good example for co-operation among nations in other fields... 》

The conference was attended by representatives from the National Societies of Indonesia, Malaysia, the Philippines, Singapore and Thailand. The Japanese Red Cross sent an observer. The League was represented by Mr. Kai Warras, its Vice-President, and the ICRC by Mr. Richard Pestalozzi, a member of the Committee.

The purpose of the meeting was to strengthen the ties uniting National Societies of the region and to prepare for the International Red Cross Conference being held this month at Bucharest. This aim, according to participants, was fully achieved.

The National Societies of the Asean countries have similar problems and intend to strengthen their co-operation, particularly in disaster relief. They are also mindful of the problems facing the world Red Cross movement as a whole and they intend to play their part in solving them.

The third conference of National Societies of the Asean countries is scheduled for 1979 and will be held in the Philippines. 